\title{
Parameter estimates for reproductive and carcass traits in Nelore beef cattle
}

\author{
M.E. Buzanskas ${ }^{a}$, P.S. Pires ${ }^{\text {a }}$, T.C.S. Chud ${ }^{a}$, P.A. Bernardes ${ }^{\text {a }}$, L.D. Rola ${ }^{\mathrm{b}}$, \\ R.P. Savegnago ${ }^{a}$, R.B. Lôbo ${ }^{c}$, D.P. Munari ${ }^{\text {a,* }}$ \\ ${ }^{a}$ Departamento de Ciências Exatas, Faculdade de Ciências Agrárias e Veterinárias, UNESP-Univ Estadual Paulista, Jaboticabal, \\ São Paulo, Brazil

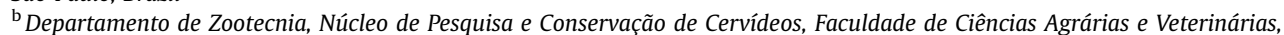 \\ UNESP-Univ Estadual Paulista, Jaboticabal, São Paulo, Brazil \\ ${ }^{\mathrm{c}}$ Associação Nacional de Criadores e Pesquisadores (ANCP), Ribeirão Preto, São Paulo, Brazil
}

\section{A R T I C L E I N F O}

\section{Article history:}

Received 3 March 2016

Received in revised form 15 September 2016

Accepted 28 September 2016

Available online 6 October 2016

\section{Keywords:}

Bos taurus indicus

Heritability

Longissimus dorsi muscle

Scrotal circumference

Selection

\begin{abstract}
A B S T R A C T
The aim of this study was to estimate genetic parameters for scrotal circumference at 365 (SC365) and 450 (SC450) days of age, age at first calving (AFC), ribeye area (REA), backfat (BF) thickness, and rump fat (RF) thickness, in order to provide information on potential traits for Nelore cattle breeding program. Genetic parameters were estimated using the Average Information Restricted Maximum Likelihood method in single- and multitrait analyses. Four different animal models were tested for SC365, SC450, REA, BF, and RF in single-trait analyses. For SC365 and SC450, the maternal genetic effect was statistically significant $(\mathrm{P}<0.01)$ and was included for multitrait analyses. The direct heritability estimates for SC365, SC450, AFC, REA, BF, and RF were equal to $0.31,0.38,0.24,0.32,0.16$, and 0.19 , respectively. Maternal heritability for SC365 and SC450 was equal to 0.06 and 0.08 , respectively. The highest genetic correlations were found among the scrotal circumferences. Testing for the inclusion of maternal effects in genetic parameters estimation for scrotal circumference should be evaluated in the Nelore breeding program, mostly for correctly ranking the animal's estimated breeding values. Similar heritability estimates were observed for scrotal circumference, as well as favorable genetic correlations of this trait with AFC and carcass traits. Thus, scrotal circumference measured at 365 days of age could be a target trait for consideration in the Nelore selection index in order to improve most of the traits herein analyzed.
\end{abstract}

(c) 2016 Published by Elsevier Inc.

\section{Introduction}

In beef cattle, the reproductive performance of the cows, which is represented by the number of calves born annually, is one of the main economic factors affecting the production system [1]. The genetic improvement of reproductive traits in females is generally challenging due to difficulties in measuring the traits as well as to the low

\footnotetext{
* Corresponding author. Tel.: +55 163209 2624; fax: +55 1632024275 . E-mail address: munari@fcav.unesp.br (D.P. Munari).
}

genetic variability, which results in a slow response to selection [2-4]. Thus, breeding programs have been considering reproductive measures taken in males (i.e., scrotal circumference) in the selection criteria due to moderate to high heritability estimates and ease of measurement [5].

Scrotal circumference is indicative of fertility and development in beef cattle, due to favorable genetic correlations with reproductive traits (semen volume, age at puberty in males and related females, and heifer pregnancy) [6-8] and production traits (body weight and longissimus muscle area) [5,9,10]. 
The carcass traits, such as ribeye area (REA) and fat thickness, are directly related to the quality of meat products, which may influence in the financial revenue received by the producers [11]. Animals with early fat deposition could be in the final stages of development, showing evidence of reproductive maturity. As observed by Foster and Nagatani [12], fat deposition could be assigned to the production of hormones, which triggers the folliculogenesis process. Thus, the aim of our study was to estimate genetic parameters for male and female reproductive traits and carcass traits in order to provide information on potential traits for Nelore cattle breeding program.

\section{Material and methods}

\subsection{Animals and data set}

The data used in this study were provided by the Nelore Genetic Improvement Program (Nelore Brazil), coordinated by the National Association of Breeders and Researchers. Animals were raised in an extensive production system and kept on pastures with mineral supplementation. Weaning occurred at around 6 to 8 months of age. The reproductive management consisted of a breeding season lasting from 90 to 120 days, using artificial insemination or controlled natural breeding.

The traits analyzed were scrotal circumference at 365 (SC365) and 450 (SC450) days of age, age at first calving (AFC), REA, subcutaneous backfat (BF) thickness measured between the 12 th and 13 th ribs, and rump fat (RF). The raw data consist of 23,129 (SC365), 25,431 (SC450), 17,586 (AFC), and 11,578 (REA, BF, and RF) animals with phenotypic information. To measure the REA, BF, and RF, ultrasound images were obtained using the ALOKA $500 \mathrm{~V}$ device, with a $3.5 \mathrm{MHz}$ linear probe measuring $17.2 \mathrm{~cm}$ and an acoustic coupler, in conjunction with an image capture system (Blackbox, Biotronics Inc., Ames, IA, USA). These images were subsequently interpreted by the laboratory responsible for data quality (Aval Serviços Tecnológicos S/ $\mathrm{S})$. These measurements were carried out at the average age of 546 days.

\subsection{Fixed effects}

The general linear model procedure of the Statistical Analysis System Software (SAS 9.1 SAS Institute, Cary, NC, USA) was used to define the fixed effects. The significant effects $(P<0.05)$ were used in the genetic parameters analyses. Sires with less than three offspring and management groups with less than five animals were excluded from the data set.

For SC365 and SC450, the significant effects $(\mathrm{P}<0.05)$ considered were farm (20 levels), birth year (from 1998 to 2008), birth season (two levels), management group at 365 days of age (for SC365), and management group at 450 days of age (for SC450). For AFC, the significant effects $(\mathrm{P}<0.05)$ considered were animals born in the same year (from 1998 to 2006) and season and at the same farm (21 levels). For the carcass traits (REA, BF, and RF), the effects of sex, birth year (from 2000 to 2008), birth season, and management group at 450 days were statistically significant $(\mathrm{P}<0.05)$. The age of the animal at ultrasound measurement was statistically significant $(P<0.05)$ and was considered as a linear and quadratic covariate for REA, BF, and RF.

The birth season was defined as rainy season (animals born between October and March) and dry season (animals born between April and September). The number of management groups at 365 and 450 days of age were 187 and 194 , respectively. The observations with standardized residuals above 3.5 or below -3.5 were excluded. The final number of records is described in Table 1.

\subsection{Genetic parameters}

Genetic parameters and standard errors were estimated using the Average Information Restricted Maximum Likelihood method under an animal model (single-trait and multitrait analyses). The total number of animals in the relationship matrix was 81,579 . Analyses were conducted using the software WOMBAT [13] considering the convergence criterion of $10^{-9}$. The general statistical model was:

$y=X \beta+Z a+M m+W p e+e$

in which $y$ is the vector of observations for each trait; $\beta$ is the vector of all fixed effects and covariate; $a$ is the vector of random additive genetic direct effect; $m$ is the vector of random maternal genetic effect; $p e$ is the vector of random maternal permanent environment effects; $e$ is the vector of random residual effects; $X, Z, M$, and $W$ are the incidence matrixes related to $\beta, a, m$, and pe, respectively.

Four different models were evaluated for SC365, SC450, REA, BF, and RF in single-trait analyses. The genetic covariance between the direct and maternal effects and the residual covariances between traits measured on opposite sex were not estimated [14].

Table 1

Number of animals, means and standard deviations, minimum and maximum values, and coefficient of variation (CV) for scrotal circumference at 365 (SC365) and 450 (SC450) days of age, age at first calving (AFC), ribeye area (REA), subcutaneous backfat thickness (BF), and rump fat (RF) in Nelore cattle.

\begin{tabular}{|c|c|c|c|c|c|c|c|}
\hline Trait & Animals & Sires & Dams & Mean \pm standard deviation & Minimum & Maximum & $\mathrm{CV}$ \\
\hline SC365 (mm) & 17,542 & 704 & 12,338 & $204 \pm 22$ & 127 & 294 & 10.89 \\
\hline $\mathrm{SC} 450(\mathrm{~mm})$ & 17,542 & 704 & 12,338 & $236 \pm 30$ & 136 & 354 & 12.70 \\
\hline $\mathrm{AFC}(\mathrm{mo})$ & 14,069 & 858 & 10,931 & $35.19 \pm 5.03$ & 21.00 & 49.00 & 14.29 \\
\hline $\operatorname{REA}\left(\mathrm{cm}^{2}\right)$ & 9776 & 405 & 7256 & $52.47 \pm 10.02$ & 22.37 & 103.55 & 19.10 \\
\hline $\mathrm{BF}(\mathrm{mm})$ & 9776 & 405 & 7256 & $2.42 \pm 0.82$ & 0.40 & 6.60 & 33.88 \\
\hline $\mathrm{RF}(\mathrm{mm})$ & 9776 & 405 & 7256 & $3.01 \pm 1.21$ & 0.40 & 10.80 & 40.20 \\
\hline
\end{tabular}


The models are defined as follows:

- Model 1 (M1): additive genetic direct and residual effects;

- Model 2 (M2): additive genetic direct, maternal permanent environment, and residual effects;

- Model 3 (M3): additive genetic direct, maternal genetic and residual effects; and

- Model 4 (M4): additive genetic direct, maternal genetic, maternal permanent environment and residual effects.

For AFC, only the M1 model was performed. The likelihood ratio test (LRT) was used to evaluate the significance of the random effects included in the model and to define an adequate model for multitrait analyses. The LRT is based on a mixed chi-squared $\left(\chi^{2}\right)$ distribution of $k-1$ and $k$ degrees of freedom under the null hypothesis of no difference between the models, with $k$ being the difference between the parameters in the models [15]. The level of significance of $1 \%$ was considered in this study.

\section{Results}

The descriptive statistics for SC365, SC450, AFC, REA, BF, and $\mathrm{RF}$ are presented in Table 1 . The genetic parameters obtained in single-trait analyses and the LRT tests are presented in Table 2. For SC365 and SC450, a reduction in -2 Log likelihood was observed when the maternal genetic and permanent environment effects were included in the model. Results indicated that the most appropriate model for SC365 and SC450 genetic evaluation was M3. For scrotal circumference, the comparison between the M3 and M4 models had no significant difference $(P>0.01)$. The most fitting model for REA, BF, and RF was M1, which considers the additive direct genetic and residual effects.

Additional analyses were carried out considering the Spearman correlation for the estimated breeding values (EBVs) obtained from models M1 and M3 for SC365 and SC450, respectively. For SC365, the Spearman correlation between the EBVs presented perfect ranking correlation (estimate equal to one), whereas SC450 presented correlation equal to 0.96 . For the top $1 \%$ animals (439 animals), the correlation for SC450 was equal to 0.77 .

The estimates of genetic parameters obtained in the multitrait analysis are presented in Table 3. The direct and maternal heritability estimates obtained in single-trait analyses were similar to the multitrait analyses. High direct heritability estimate was observed for SC450, followed by REA and SC365. Standard errors varied from 0.01 to 0.03 for direct and maternal heritability estimates. Genetic correlations ranged from 0.01 to 0.94 in the multitrait analysis. The highest genetic correlations were observed between SC365 and SC450 (0.94 \pm 0.01$)$ and between RF and BF (0.59 \pm 0.07$)$. Negative genetic correlations between AFC and the other traits were observed. Genetic correlations with low confidence were observed between RF with SC365, SC450, and AFC and between AFC with REA.

\section{Discussion}

The overall means for SC365, SC450, and AFC found by Grossi et al. [2], Yokoo et al. [9], and Barrozo et al. [16] in Nelore cattle, respectively, were in agreement with our

Table 2

Genetic parameters obtained by means of single-trait analysis for scrotal circumference at 365 (SC365) and 450 (SC450) days of age, age at first calving (AFC), ribeye area (REA), subcutaneous backfat thickness (BF), and rump fat (RF) in Nelore cattle.

\begin{tabular}{|c|c|c|c|c|c|c|c|c|c|}
\hline \multirow[t]{2}{*}{ Traits } & \multirow[t]{2}{*}{ Model } & \multirow[t]{2}{*}{$h_{a}^{2} \pm \mathrm{SE}$} & \multirow[t]{2}{*}{$h_{m}^{2} \pm \mathrm{SE}$} & \multirow[t]{2}{*}{$c^{2} \pm \mathrm{SE}$} & \multirow[t]{2}{*}{$-2 \log \mathrm{L}$} & \multicolumn{4}{|l|}{ LRT } \\
\hline & & & & & & M2-M1 & M3-M1 & M4-M2 & M4-M3 \\
\hline \multirow[t]{4}{*}{ SC365 } & M1 & $0.45 \pm 0.02$ & - & - & $116,085.29$ & $11.68^{\mathrm{a}}$ & $99.79^{\mathrm{a}}$ & $88.11^{\mathrm{a}}$ & $0.00^{(\mathrm{ns})}$ \\
\hline & M2 & $0.40 \pm 0.02$ & - & $0.04 \pm 0.01$ & $116,073.61$ & - & - & - & - \\
\hline & M3 & $0.36 \pm 0.03$ & $0.07 \pm 0.01$ & - & $115,985.50$ & - & - & - & - \\
\hline & M4 & $0.36 \pm 0.03$ & $0.07 \pm 0.01$ & $0.00 \pm 0.01$ & $115,985.50$ & - & - & - & - \\
\hline \multirow[t]{4}{*}{ SC450 } & M1 & $0.49 \pm 0.02$ & - & - & $125,091.55$ & $11.20^{\mathrm{a}}$ & $107.69^{\mathrm{a}}$ & $96.49^{\mathrm{a}}$ & $0.00^{(\mathrm{ns})}$ \\
\hline & M2 & $0.44 \pm 0.03$ & - & $0.04 \pm 0.01$ & $125,080.34$ & - & - & - & - \\
\hline & M3 & $0.38 \pm 0.02$ & $0.08 \pm 0.01$ & - & $124,983.85$ & - & - & - & - \\
\hline & M4 & $0.38 \pm 0.01$ & $0.08 \pm 0.01$ & $0.01 \pm 0.01$ & $124,983.85$ & - & - & - & - \\
\hline AFC & M1 & $0.25 \pm 0.02$ & - & - & - & - & - & - & - \\
\hline \multirow[t]{4}{*}{ REA } & M1 & $0.31 \pm 0.03$ & - & - & $43,858.52$ & $0.00^{(\mathrm{ns})}$ & $3.82^{(\mathrm{ns})}$ & $3.82^{(\mathrm{ns})}$ & $0.00^{(\mathrm{ns})}$ \\
\hline & M2 & $0.31 \pm 0.03$ & - & $0.00 \pm 0.00$ & $43,858.52$ & - & - & - & - \\
\hline & M3 & $0.29 \pm 0.03$ & $0.02 \pm 0.01$ & - & $43,854.70$ & - & - & - & - \\
\hline & M4 & $0.29 \pm 0.03$ & $0.02 \pm 0.01$ & $0.00 \pm 0.00$ & $43,854.70$ & - & - & - & - \\
\hline \multirow[t]{4}{*}{$\mathrm{BF}$} & M1 & $0.18 \pm 0.03$ & - & - & -4069.75 & $0.00^{(\mathrm{ns})}$ & $0.08^{(\mathrm{ns})}$ & $0.08^{(\mathrm{ns})}$ & $0.00^{(\mathrm{ns})}$ \\
\hline & M2 & $0.18 \pm 0.03$ & - & $0.01 \pm 0.01$ & -4069.75 & - & - & - & - \\
\hline & M3 & $0.18 \pm 0.03$ & $0.003 \pm 0.01$ & - & -4069.83 & - & - & - & - \\
\hline & M4 & $0.17 \pm 0.02$ & $0.003 \pm 0.01$ & $0.00 \pm 0.00$ & -4069.83 & - & - & - & - \\
\hline \multirow[t]{4}{*}{$\mathrm{RF}$} & M1 & $0.19 \pm 0.03$ & - & - & 3233.87 & $0.00^{(\mathrm{ns})}$ & $0.02^{\text {(ns) }}$ & $0.02^{\text {(ns) }}$ & $0.00^{(\mathrm{ns})}$ \\
\hline & M2 & $0.19 \pm 0.02$ & - & $0.00 \pm 0.00$ & 3233.87 & - & - & - & - \\
\hline & M3 & $0.19 \pm 0.02$ & $0.001 \pm 0.01$ & - & 3233.85 & - & - & - & - \\
\hline & M4 & $0.19 \pm 0.03$ & $0.001 \pm 0.01$ & $0.00 \pm 0.00$ & 3233.85 & - & - & - & - \\
\hline
\end{tabular}

\footnotetext{
a Significantly different from zero $\left(\mathrm{LRT} \leq X_{(1 \%)}^{2}\right) ;{ }^{(\mathrm{ns})}$ Not significantly different from zero (LRT $\left.>X_{(1 \%)}^{2}\right) ; \mathrm{M} 1=y=X \beta+Z a+e ; \mathrm{M} 2=y=X \beta+Z a+W p e+e$; $\mathrm{M} 3=y=X \beta+Z a+M m+e ; \mathrm{M} 4=y=X \beta+Z a+M m+W p e+e ; h_{a}^{2}=$ direct heritability estimate; $h_{m}^{2}=$ maternal heritability estimate; $c^{2}=$ proportion of maternal permanent environmental variance to total variance; $-2 \operatorname{LogL}=$ two times the logarithm of the likelihood; LRT $=$ likelihood ratio test; $\mathrm{SE}=$ standard error; $X_{(1 \%)}^{2}=6.63$.
} 
Table 3

Direct and maternal heritability estimates (diagonal) for scrotal circumference at 365 (SC365) and 450 (SC450) days of age, age at first calving (AFC), ribeye area (REA), subcutaneous backfat thickness (BF), and rump fat (RF), and their respective standard errors ( \pm ) obtained in multitrait analysis.

\begin{tabular}{|c|c|c|c|c|c|c|}
\hline Trait & SC365 & SC450 & AFC & REA & $\mathrm{BF}$ & RF \\
\hline SC365 & $\begin{array}{l}0.31 \pm 0.02^{\mathrm{a}} \\
0.06 \pm 0.01^{\mathrm{b}}\end{array}$ & $0.94 \pm 0.01$ & $-0.50 \pm 0.06$ & $0.33 \pm 0.07$ & $0.31 \pm 0.09$ & $0.05 \pm 0.09$ \\
\hline SC450 & $0.78 \pm 0.01$ & $\begin{array}{l}0.38 \pm 0.03^{\mathrm{a}} \\
0.08 \pm 0.01^{\mathrm{b}}\end{array}$ & $-0.46 \pm 0.06$ & $0.31 \pm 0.07$ & $0.25 \pm 0.09$ & $0.01 \pm 0.09$ \\
\hline $\mathrm{AFC}$ & - & - & $0.24 \pm 0.02^{a}$ & $-0.12 \pm 0.08$ & $-0.29 \pm 0.10$ & $-0.08 \pm 0.09$ \\
\hline REA & $0.14 \pm 0.04$ & $0.23 \pm 0.04$ & $-0.04 \pm 0.05$ & $0.32 \pm 0.03^{\mathrm{a}}$ & $0.36 \pm 0.08$ & $0.23 \pm 0.08$ \\
\hline $\mathrm{BF}$ & $-0.01 \pm 0.03$ & $0.01 \pm 0.03$ & $-0.16 \pm 0.04$ & $0.18 \pm 0.02$ & $0.16 \pm 0.02^{a}$ & $0.59 \pm 0.07$ \\
\hline RF & $0.02 \pm 0.03$ & $0.02 \pm 0.04$ & $-0.20 \pm 0.04$ & $0.19 \pm 0.02$ & $0.48 \pm 0.01$ & $0.19 \pm 0.02^{\mathrm{a}}$ \\
\hline
\end{tabular}

Above and below the diagonals are presented the genetic and environmental correlations, respectively, in Nelore cattle.

a Direct heritability estimates.

b Maternal heritability estimates; - = residual covariances between traits measured on opposite sex were not estimated.

results (204 mm, $236 \mathrm{~mm}$, and 35 months, respectively). The overall means for the REA, BF, and RF found in this study (Table 1) were similar to the results obtained by Yokoo et al. [9] and Gordo et al. [17].

The maternal genetic effect was tested for scrotal circumferences and carcass traits (Table 2). Despite of the low maternal heritability estimates obtained in single-trait and multitrait analyses for SC365 $(0.07 \pm 0.01$ and $0.06 \pm 0.01)$ and SC450 $(0.08 \pm 0.01$ and $0.08 \pm 0.01)$, these effects were statistically significant $(\mathrm{P}<0.01)$. According to Crews Jr. and Enns [18], maternal effects could be relatively negligible due to low estimates and the M1 would be the most practicable and run-time efficient model for analysis of SC365. The Spearman correlation between the EBVs for SC450 indicates that the ranking of the animals could be altered according to the model used for genetic parameters estimation. Perfect correlation between M1 and M3 was observed for SC365, indicating that the EBVs may not be altered in ranking but it could be overestimated if M1 was chosen for the genetic evaluation.

Regarding the maternal permanent environmental effect, the presence of cows with a low number of calves in genetic evaluations may result in confounded effects between maternal genetic and maternal permanent environmental random effects [19]. Thus, the significance observed between $\mathrm{M} 1$ and $\mathrm{M} 2$ and between $\mathrm{M} 1$ and $\mathrm{M} 3$, for SC365 and SC450, could reflect the maternal structure of the analyzed data (Table 2). The maternal genetic effect was confirmed when the significant difference $(\mathrm{P}<0.01)$ was observed between M2 and M4, for SC365 and SC450.

The direct heritability estimates for SC365, SC450, and REA were considered moderate (Table 3 ). Thus, these traits provided evidence that a substantial proportion of the variation in these traits is determined by genes of additive action and could respond to selection. Similar results were observed by Frizzas et al. [5] for scrotal circumference measured at 12 and 18 months of age in Nelore cattle. Terakado et al. [20] obtained direct heritability estimates for SC365 and SC450 equal to 0.35 and 0.40 , respectively. For REA, Yokoo et al. [9] and Zuin et al. [21] found similar direct heritability estimates to our results in the Nelore breed.

Direct and maternal heritability estimates for scrotal circumference at weaning obtained by Pires et al. [22] were equal to $0.32 \pm 0.06$ and $0.06 \pm 0.02$, respectively, in Canchim beef cattle. For scrotal circumference at yearling age, these authors found direct heritability estimate of $0.49 \pm 0.08$. For the Angus breed, Morris et al. [23] and Garmyn et al. [24] estimated direct heritabilities for scrotal circumference at weaning and yearling age equal to $0.37 \pm 0.06$ and $0.46 \pm 0.08$, respectively. For REA, Crews Jr. et al. [25] and Mao et al. [26] obtained heritability estimates equal to $0.46 \pm 0.05$ and $0.64 \pm 0.15$ in the Simmental and Charolais breeds, respectively.

According to Cammack et al. [27], the heritability estimates for female reproductive traits are generally low in beef cattle. However, Åby et al. [28] highlighted that reproductive traits are economically important to the production system and that the genetic potential of herds could be slowly enhanced over the years through selection. The heritability estimate found in our study for AFC was equal to $0.24 \pm 0.02$. This estimate was higher than most of the consulted literature for the Nelore breed [4,29-31]. Martínez-Velázquez et al. [32] and Bernardes et al. [33] obtained heritability estimates of $0.28 \pm 0.06$ and $0.09 \pm 0.02$ in Angus heifers and Tabapuã beef cattle, respectively.

As the selection process has been conducted over the years in the Nelore herd (Nelore Brazil Program), the genetic variability is being introduced and precocious heifers are being selected. A better-controlled environment could also be affecting the heritability estimate observed for AFC. The genetic trends from 1988 to 2003 presented by Grossi et al. [29] indicated significant reduction ( $P<0.01$ ) for AFC. Furthermore, minimum and maximum phenotypic values for AFC observed by these authors were equal to 27 and 49 months, respectively, whereas values equal to 21 and 49 were observed in our study. However, the overall mean for this trait remains unaltered $[2,11,16]$.

Low direct heritability estimates were observed for BF and RF (Table 3); thus, slow response to direct selection for these traits would be expected. This result could be indicative of low genetic variability for these traits when the ultrasound measures were taken, which suggests that Nelore cattle present late fat deposition; Yokoo et al. [9] and Zuin et al. [21] found higher heritability estimates for BF and $\mathrm{RF}$, equal to 0.50 and 0.21 , and 0.39 and 0.23 , respectively. For Angus and Brangus breeds, Kemp et al. [34] and Moser et al. [35] obtained heritability estimates for BF equal to 0.39 and $0.11 \pm 0.03$, respectively. Reverter et al. [36] observed heritability estimates for RF data obtained in abattoirs equal to 0.44 and 0.08 in Angus and Hereford 
breeds. The same authors estimated the heritability for RF measured by ultrasound in bulls and heifers of Angus and Hereford breeds, which was equal to 0.51 and 0.75 , and 0.25 and 0.37 , respectively.

The genetic correlations between AFC and REA and between RF with SC365, SC450, and AFC presented high standard errors (Table 3), indicating no reliability for these estimates and no linear association among the traits. A high genetic correlation was observed between SC365 and SC450 (0.94 \pm 0.01$)$, which means that the genes of addictive action that are acting in younger ages are still acting in later ages. Boligon et al. [10] and Yokoo et al. [37] observed a high genetic correlation between scrotal circumferences measured at different ages and suggested that adequate response to selection would be achieved if postweaning scrotal circumferences are used.

Favorable genetic correlations were observed between the scrotal circumferences and AFC (Table 3), which indicates a common genetic background that controls these traits. Evidence of gonadotrophic hormones acting on male and female physiological development and reproductive activity has been reported by Land [38]. According to Lunstra et al. [39], animals with higher scrotal circumference could achieve puberty earlier. Furthermore, the hormonal background which promotes the testicular development in males is also acting in the ovarium development in females [40]. Similar results were observed by Grossi et al. [2] for the genetic correlations between AFC with SC365 and SC450. For genetic correlation between AFC and scrotal circumference at 550 days of age, Pereira et al. [41] found estimates which varied from -0.23 to -0.29 . In addition, Santana et al. [30] highlighted that scrotal circumference measures obtained after 440 days of age presented higher genetic correlations with AFC.

Moderate to low genetic correlations were obtained between scrotal circumferences with REA and BF; however, estimates were favorable (Table 3). Thus, selection for SC365 or SC450 would promote slow improvement in carcass traits. Yokoo et al. [37] found similar results for these traits and suggested the existence of low pleiotropic effects. Low genetic correlations between the described traits were observed by Barbosa et al. [42] and Marques et al. [43] in the Nelore breed.

The genetic correlation between AFC and BF may indicate that fat deposition is a requirement for calving performance. One of the factors which influence the onset of early estrus is the fat deposition, considering that the hypothalamus is programmed via the Leptin, which is a fatderived hormone [12]. According to Cunningham et al. [44], Leptin has the potential to act as a metabolic signal to indicate that the energy reserves are sufficient for initiating the onset of puberty and reproduction. Caetano et al. [11] observed a high genetic correlation between AFC and BF and suggested that animals with higher RF present early carcass finishing, which may influence the sexual precocity.

Carcass traits presented genetic correlations varying from $0.23 \pm 0.08$ to $0.59 \pm 0.07$ (Table 3 ), indicating that selection for any of these traits would benefit the others. One of the first stages of animal's growth is muscular development, followed by fat deposition [45]. Thus, animals with early muscular development could be precocious in fat deposition and present better carcass quality. Zuin et al. [21] estimated genetic correlations between REA and BF, REA and RF, and BF and RF equal to $0.15,0.09$, and 0.64 , respectively. Similar results were found for the same traits by Lima Neto et al. [46] and Yokoo et al. [9]. High genetic correlation between $\mathrm{BF}$ and $\mathrm{RF}$ was expected because both have similar tissue features and are largely determined by the same sets of genes with additive action.

\subsection{Conclusions}

Testing for the inclusion of maternal effects in genetic parameter estimation for scrotal circumference should be evaluated in the Nelore breeding program, mostly for correctly ranking the animal's EBVs. Similar heritability estimates were observed for scrotal circumferences, as well as moderate and favorable genetic correlations of this trait with AFC and carcass traits. Thus, scrotal circumference measured at 365 days of age would be a target trait to be considered in the Nelore selection index in order to improve most of the traits herein analyzed.

\section{Acknowledgments}

The authors acknowledge the National Breeders' and Researchers' Association (Associação Nacional de Criadores e Pesquisadores-ANCP). The authors thank São Paulo Research Foundation (FAPESP) for the fellowship received by M.E. Buzanskas (2013/19335-2), T.C.S. Chud (2015/ 08939-0), L.D. Rola (2013/13972-0), R.P. Savegnago (2013/ 20091-0), and P.A. Bernardes (2015/25096-6). R.B. Lôbo, and D.P. Munari are CNPq (Conselho Nacional de Desenvolvimento Científico e Tecnológico) fellows.

\section{Competing interests}

The authors declare no conflicts of interest.

\section{References}

[1] Chud TCS, Caetano SL, Buzanskas ME, Grossi DA, Guidolin DGF, Nascimento GB, et al. Genetic analysis for gestation length, birth weight, weaning weight, and accumulated productivity in Nellore beef cattle. Livest Sci 2014;170:16-21.

[2] Grossi DA, Venturini GC, Paz CCP, Bezerra LAF, Lôbo RB, Oliveira JA, et al. Genetic associations between age at first calving and heifer body weight and scrotal circumference in Nelore cattle. J Anim Breed Genet 2009;126:387-93.

[3] Buzanskas ME, Grossi DA, Baldi F, Barrozo D, Silva LOC, Torres Júnior RAA, et al. Genetic associations between stayability and reproductive and growth traits in Canchim beef cattle. Livest Sci 2010;132:107-12.

[4] Eler JP, Bignardi AB, Ferraz JBS, Santana JL. Genetic relationships among traits related to reproduction and growth of Nelore females. Theriogenology 2014;82:708-14.

[5] Frizzas OG, Grossi DA, Buzanskas ME, Paz CCP, Bezerra LAF, Lôbo RB, et al. Heritability estimates and genetic correlations for body weight and scrotal circumference adjusted to 12 and 18 months of age for male Nellore cattle. Animal 2009;3:347-51.

[6] Latif M, Ahmed J, Bhuiyan M, Shamsuddin M. Relationship between scrotal circumference and semen parameters in crossbred bulls. Bangladesh Vet 2010;26:61-7.

[7] Van-Melis MH, Eler JP, Rosa GJM, Ferraz JBS, Figueiredo LGG, Mattos EC, et al. Additive genetic relationships between scrotal circumference, heifer pregnancy, and stayability in Nellore cattle. J Anim Sci 2010;88:3809-13. 
[8] Fortes MRS, Lehnert SA, Bolormaa S, Reich C, Fordyce G, Corbet NJ, et al. Finding genes for economically important traits: Brahman cattle puberty. Anim Prod Sci 2012;52:143-50.

[9] Yokoo MJ, Lobo RB, Araujo FRC, Bezerra LAF, Sainz RD, Albuquerque LG. Genetic associations between carcass traits measured by real-time ultrasound and scrotal circumference and growth traits in Nelore cattle. J Anim Sci 2010;88:52-8.

[10] Boligon AA, Baldi F, de Albuquerque LG. Genetic parameters and relationships between growth traits and scrotal circumference measured at different ages in Nellore cattle. Genet Mol Biol 2011; 34:225-30.

[11] Caetano SL, Savegnago RP, Boligon AA, Ramos SB, Chud TCS, Lôbo RB, et al. Estimates of genetic parameters for carcass, growth and reproductive traits in Nellore cattle. Livest Sci 2013;155:1-7.

[12] Foster DL, Nagatani S. Physiological perspectives on leptin as a regulator of reproduction: role in timing puberty. Biol Reprod 1999; 60:205-15.

[13] Meyer K. WOMBAT: a tool for mixed model analyses in quantitative genetics by restricted maximum likelihood (REML). J Zhejiang Univ Sci B 2007;8:815-21.

[14] Albuquerque LG, Meyer K. Estimates of direct and maternal genetic effects for weights from birth to 600 days of age in Nelore cattle. J Anim Breed Genet 2001;118:83-92.

[15] Self SG, Liang KY. Asymptotic properties of maximum likelihood estimators and likelihood ratio tests under nonstandard conditions. J Am Stat Assoc 2009;82:605-10.

[16] Barrozo D, Buzanskas ME, Oliveira JA, Munari DP, Neves HHR Queiroz SA. Genetic parameters and environmental effects on temperament score and reproductive traits of Nellore cattle. Animal 2012;6:36-40.

[17] Gordo DGM, Baldi F, Lôbo RB, Filho WK, Sainz RD, Albuquerque LG. Genetic association between body composition measured by ultrasound and visual scores in Brazilian Nelore cattle. J Anim Sci 2012; 90:4223-9.

[18] Crews Jr DH, Enns RM. Models for genetic evaluation of scrotal circumference in Red Angus. Prof Anim Sci 2008;24:128-35.

[19] Pelicioni LC, Queiroz SA, Albuquerque LG. Estimativas de parâmetros genéticos para pesos ao nascer e mensais até 450 dias em bovinos Guzerá. Arch Latinoam Prod Anim 2003;11:34-9.

[20] Terakado APN, Boligon AA, Baldi F, Silva JA II V, Albuquerque LG. Genetic associations between scrotal circumference and female reproductive traits in Nelore cattle. J Anim Sci 2015;93:2706-13.

[21] Zuin RG, Buzanskas ME, Caetano SL, Venturini GC, Guidolin DGF, Grossi DA, et al. Genetic analysis on growth and carcass traits in Nelore cattle. Meat Sci 2012;91:352-7.

[22] Pires BC, Tholon P, Buzanskas ME, Sbardella AP, Rosa JO, Silva LOC et al. Genetic analyses on body weight, reproductive, and carcass traits in composite beef cattle. Anim Prod Sci. http://dx.doi.org/10. 1071/AN15458; 2016.

[23] Morris CA, Wilson JA, Bennett GL, Cullen NG, Hickey SM, Hunter JC. Genetic parameters for growth, puberty, and beef cow reproductive traits in a puberty selection experiment. New Zeal J Agric Res 2000; 43:83-91.

[24] Garmyn AJ, Moser DW, Christmas RA, Minick Bormann J. Estimation of genetic parameters and effects of cytoplasmic line on scrotal circumference and semen quality traits in Angus bulls. J Anim Sci 2011;89:693-8.

[25] Crews Jr DH, Pollak RL, Weaber RL, Quaas RL, Lipsey RJ. Genetic parameters for carcass traits and their live animal indicators in Simmental cattle. J Anim Sci 2003;81:1427-33.

[26] Mao F, Chen L, Vinsky M, Okine E, Wang Z, Basarab J, et al. Phenotypic and genetic relationships of feeding behavior with feed intake, growth performance, feed efficiency, and carcass merit traits in Angus and Charolais steers. J Anim Sci 2013:91:2067-76.
[27] Cammack KM, Thomas MG, Enns RM. Reproductive traits and their heritabilities in beef cattle. Prof Anim Sci 2009;25:517-28.

[28] Åby BA, Aass L, Sehested E, Vangen O. Effects of changes in external production conditions on economic values of traits in Continental and British beef cattle breeds. Livest Sci 2012;150:80-93.

[29] Grossi DA, Frizzas OG, Paz CCP, Bezerra LAF, Lôbo RB, Oliveira JA et al. Genetic associations between accumulated productivity, and reproductive and growth traits in Nelore cattle. Livest Sci 2008;117: 139-46.

[30] Santana ML, Eler JP, Bignardi AB, Ferraz JBS. Two-trait random regression model to estimate the genetic association of scrotal circumference with female reproductive performance in Nelore cattle. Theriogenology 2015;83:1534-40.

[31] Boligon AA, Albuquerque LG. Genetic parameters and relationships of heifer pregnancy and age at first calving with weight gain, yearling and mature weight in Nelore cattle. Livest Sci 2011;141:12-6.

[32] Martínez-Velázquez G, Gregory KE, Bennett GL, Van Vleck LD. Genetic relationships between scrotal circumference and female reproductive traits. J Anim Sci 2003;81:395-401.

[33] Bernardes PA, Grossi DA, Savegnago RP, Buzanskas ME, Urbinati I Bezerra LAF, et al. Estimates of genetic parameters and genetic trends for reproductive traits and weaning weight in Tabapuã cattle. J Anim Sci 2015;93:5175-85.

[34] Kemp DJ, Herring WO, Kaiser CJ. Genetic and environmental parameters for steer ultrasound and carcass traits. J Anim Sci 2002; 80:1489-96.

[35] Moser DW, Bertrand JK, Misztal I, Kriese LA, Benyshek LL. Genetic parameter estimates for carcass and yearling ultrasound measurements in Brangus cattle. J Anim Sci 1998;76:2542-8.

[36] Reverter A, Johnston DJ, Graser HU, Wolcott ML, Upton WH. Genetic analyses of live-animal ultrasound and abattoir carcass traits in Australian Angus and Hereford cattle. J Anim Sci 2000;78:1786-95.

[37] Yokoo MJI, Albuquerque LG, Lôbo RB, Sainz RD, Carneiro JM, Bezerra LAF, et al. Estimativas de parâmetros genéticos para altura do posterior, peso e circunferência escrotal em bovinos da raça Nelore. Rev Bras Zootec 2007;36:1761-8.

[38] Land RB. The expression of female sex-limited characters in the male. Nature 1973;241:208-9.

[39] Lunstra DD, Ford JJ, Echternkamp SE. Puberty in beef bulls: hormone concentrations, growth, testicular development, sperm production and sexual aggressiveness in bulls of different breeds. J Anim Sci 1978;46:1054-62.

[40] Mackinnon MJ, Taylor JF, Hetzel DJ. Genetic variation and covariation in beef cow and bull fertility. J Anim Sci 1990;68:1208-14.

[41] Pereira E, Eler JP, Costa FAA, Ferraz JBS. Análise genética da idade ao primeiro parto e do perímetro escrotal em bovinos da raça Nelore. Arq Bras Med Vet Zootec 2001;53:116-21.

[42] Barbosa V, Magnabosco CU, Trovo JBF, Faria CU, Lopes DT, Viu MADO, et al. Estudo genético quantitativo de características de carcaça e perímetro escrotal, utilizando inferência bayesiana em novilhos nelore. Biosci J 2010;26:789-97.

[43] Marques EG, Magnabosco CU, Lopes FB, Silva MC. Estimativas de parâmetros genéticos de características de crescimento, carcaça e perímetro escrotal de animais da raça Nelore avaliados em provas de ganho em peso em confinamento. Biosci J 2013;29:159-67.

[44] Cunningham MJ, Clifton DK, Steiner RA. Leptin's actions on the reproductive axis: perspectives and mechanisms. Biol Reprod 1999; $60: 216-22$

[45] Owens FN, Dubeski P, Hanson CF. Factors that alter the growth and development of ruminants. J Anim Sci 1993;71:3138-50.

[46] Lima Neto HR, Bergmann JAG, Gonçalves TM, Araújo FRC, Bezerra LAF, Saiz RD, et al. Parâmetros genéticos para características de carcaça avaliadas por ultrassonografia em bovinos da raça Guzerá. Arq Bras Med Vet Zootec 2009;61:251-8. 